\title{
BASIC MORPHOLOGICAL AND MORPHOSTRUCTURAL CHARACTERISTICS OF THE RAKITNICA CANYON (DINARIC KARST, BOSNIA AND HERZEGOVINA)
}

\author{
OSNOVNE MORFOLOŠKE IN MORFOSTRUKTURNE \\ ZNAČILNOSTI KANJONA RAKITNICE \\ (DINARSKI KRAS, BOSNA IN HERCEGOVINA)
}

ALEN LEPIRICA $^{1}$

\footnotetext{
${ }^{1}$ Institut za građevinarstvo, Integral Inzenjering, 51000 Banja Luka, Bosnia and Herzegovina, fax: +387.33.659-687 e-mail: vektori@bih.net.ba
} 


\title{
Abstract
}

UDC: 911.2:551.435.1(479.6)

\section{Alen Lepirica: Basic morphological and morphostructural characteristics of the Rakitnica canyon (Dinaric} Karst, Bosnia and Herzegovina)

The canyon valley of the Rakitnica river is one of the deepest and longest in the Dinaric karst. The paper states the basic morphological and morphostructural characteristics of the canyon, and gives its geomorphological regionalization. High level of correlation between lithology, tectonics and relief of the researched area has been determined. Genesis and development of this relief form have been considerably guided by neotectonic processes during the Quaternary.

Key words: Rakitnica canyon, fault neotectonics, deep fluvial incisions, Dinaric karst.

Izvleček

UDK: 911.2:551.435.1(479.6)

\begin{abstract}
Alen Lepirica: Osnovne morfološke in morfostrukturne značilnosti kanjona Rakitnice (Dinarski kras, Bosna in Hercegovina)
\end{abstract}

Kanjonska dolina reke Rakitnice je ena izmed najglobljih in najdaljših na Dinarskem krasu. Prispevek obravnava osnovne morfološke in morfostrukturne značilnosti kanjonske doline in njeno geomorfološko regionalizacijo. Poudarjena je zlasti močna povezava med litologijo, tektoniko in reliefom, saj so znatno vlogo pri razvoju te reliefne oblike odigrali zlasti neotektonski procesi v kvartarju.

Ključne besede: kanjon Rakitnice, prelomna neotektonika, globoko fluvialno vrezovanje, Dinarski kras. 


\section{INTRODUCTION}

The drainage basin and valley of the Rakitnica River, as a part of the upper Neretva River system, is situated in the central part of the Dinaric mountain range. More precisely, the valley is situated in the Central high Dinarides, between the folded block-thrusted massifs - morphostructures of Mt. Bjelašnica and Mt. Visočica, in the central part of Bosnia and Herzegovina (Fig.1).

The composite valley of the Rakitnica River has been poorly explored and researched up to now. It was mentioned for the first time in 1956, when a team of journalists, alpinists, nature scientists and soldiers visited the canyon.

In a small study, Bušatlija (1973) presented the general geomorphological and morphogenetic characteristics of the valley. Golubovic (1976) discussed some geographic issues of the Rakitnica. Lepirica (1991) gave the general geographic review of this area, with detailed morphographic description of the riverbed and lower parts of the valley sides, as well as the morphogenetic issues of the area. The same author (Lepirica 2004) carried out the comprehensive geomorphologic analysis and geo-ecological valorization of the Rakitnica canyon.

\section{POSITION AND GEOLOGICAL SETTINGS}

The drainage basin of the Rakitnica River belongs to the river system of the Neretva, feeding into the Adriatic Sea, and it is situated along the watershed between the Adriatic and the Black Sea. Regarding the fact that the researched area consists of permeable, fissured and karstified carbonates, it is terminologically more precise to use the term 'hydrogeological system of the Rakitnica' than the 'drainage basin', because it is mostly fed from the underground - by karst springs along its canyon.

The bottom and the sides of the Rakitnica valley are parts of the slopes of Mt. Visočica and Mt. Bjelašnica (Fig. 2). Adjoining mountain morphostructures of Mt.Lelija (2032 m a.s.l.) and Mt.Zelengora (2015 m a.s.l.) on the south-east, Mt.Crvanj (1921 m a.s.l.) on the south and Mt.Prenj (2103 $\mathrm{m}$ a.s.l.) on the south-west also have the folded block-thrusted structural genetic characteristics and similar elevations as Mt.Bjelašnica (2067 m a.s.l.) and Mt.Visočica (1974 m a.s.l.). All the mentioned mountain massifs are dissected by deep valleys (canyons and gorges) of allogenic streams in the upper Neretva river system and its tributaries. The valleys are composite, characterised by a repeated sequence of narrower and wider parts.

Lithologically, most part of the researched area is built of a thick series of Triassic limestones and dolomites that are considerably fissured. The higher upstream parts of the valley are partially developed in flysch.

Tectonically, the Rakitnica valley is formed at the contact of macro-tectonic units of External and Central Dinarides, in the zone of deep and high Dinaric karst. Tectonic structural and lithostratigraphical unit Bjelašnica - Visočica, in which the Rakitnica river basin is developed, is basically defined from the south-west by the fault Dubočani - Džepi (continuation of the fault Dubočani - Grušča) and from the north-east by the fault Umoljani - Tušila (Fig.3). This unit is a slightly undulating plate which is almost horizontally thrust over the structural unit Crvanj - Morine. At the east and north-east, this plate is 'sinking' below the Jurassic-Cretaceous clastic rocks.

The fault Bahtijevica - Grušča separates the Bjelašnica block (a plate of Triassic limestones and dolomites) from the Visočica block (a monocline dipping towards the east, thrust over the zone of 
"Durmitor flysch" on the south-west).

The mountains Bjelašnica and Visočica, in the structural-genetic sense, represent folded blockthrusted structures. These are massifs of Tertiary and pre-Tertiary folding, and reverse faulting with thrust structure development and napping.

Dominant orientation of transversal faults is NNW-SSE. "Reverse faults with thrust structure development and napping are caused by decrease of intensity of convectional movements upward to the surface, and the collision with the Dinaric platform. Genetically, these are all morphostructures of Mesozoic-Tertiary folding with particular uplift during the Quaternary (Pleistocene)" (Bognar 1987).

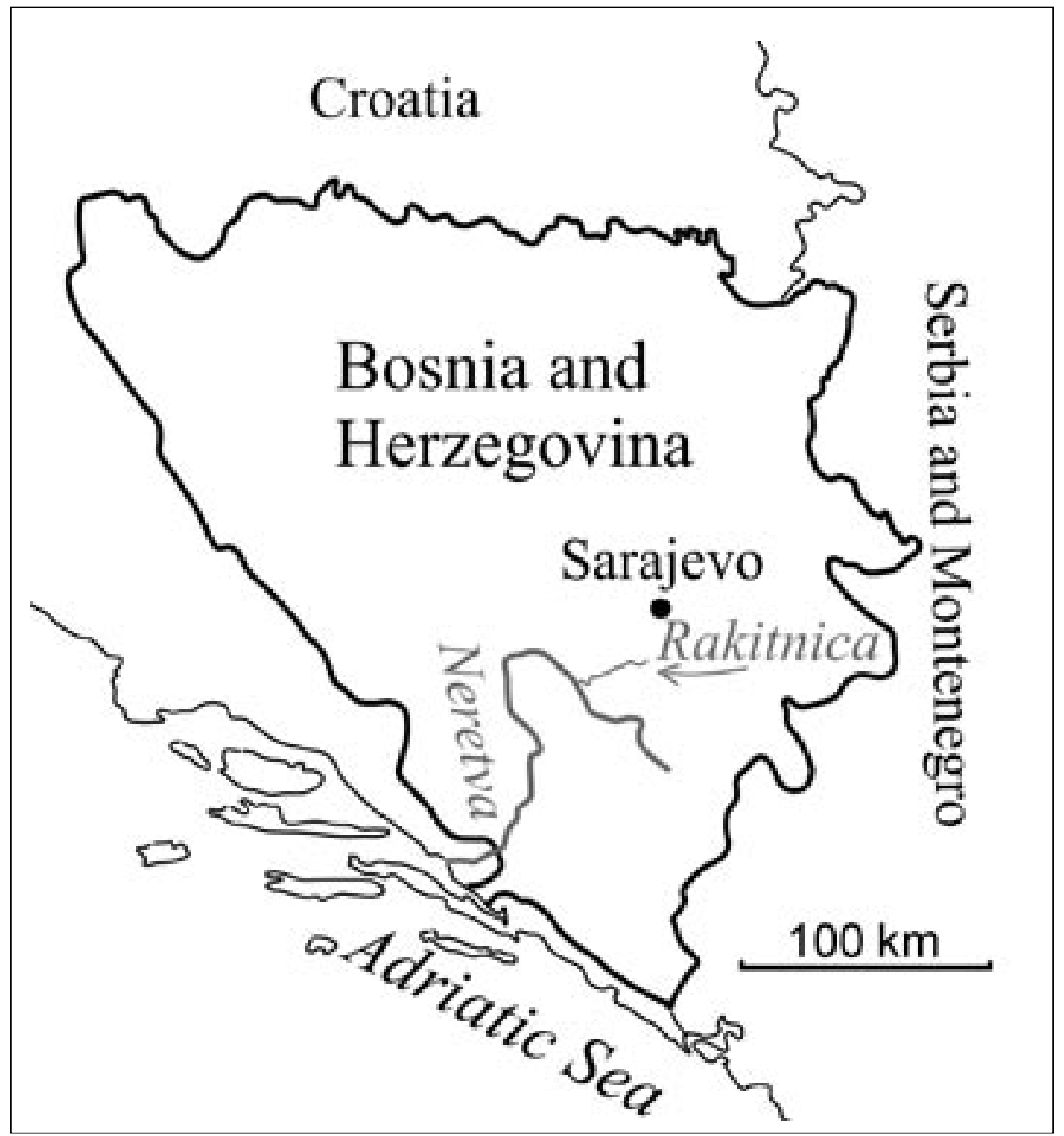

Fig.1: Geographic position of the Rakitnica River. 
GENERAL MORPHOLOGIC CHARACTERISTICS OF THE VALLEY

In the upper part of the Neretva river system, karst and fluviokarst relief dominates, particularly on high levelled surfaces, plateaus of the mentioned mountain massifs, in a large elevation range from 1000 to $2103 \mathrm{~m}$ a.s.l. On highest elevations (above $1500 \mathrm{~m}$ a.s.l.), the fragments of paleoglaciofluvial relief can be found - roches moutonnées, fossil cirques and morraines, considerably masked by recent geomorphological processes.

Occurrences of intensive destructive weathering processes are found on steeply inclined slopes of mountain ridges, as well as on escarpments of canyon sectors of valleys. In the researched part of the high Central Dinarides, various denudational processes are active (erosion, mass movements, corrosion, cryoturbation - in winter and early spring, etc.). Fluviodenudational and fluvial relief, with its erosional and accumulational forms, is developed mostly in basins lower than $800 \mathrm{~m}$ a.s.l. and in composite valleys of the rivers Neretva, Rakitnica, Ljuta, Jezernica, Bijela, Idbar and Trešanica. Regarding morphological evolution, the recent relief in the area south of the Neretva through gorge (from Jablanica on the west to the Sutjeska through gorge on the east) was formed during the neotectonic phase (Neogene-Quaternary) in which the relief has been uplifted to the present elevations.

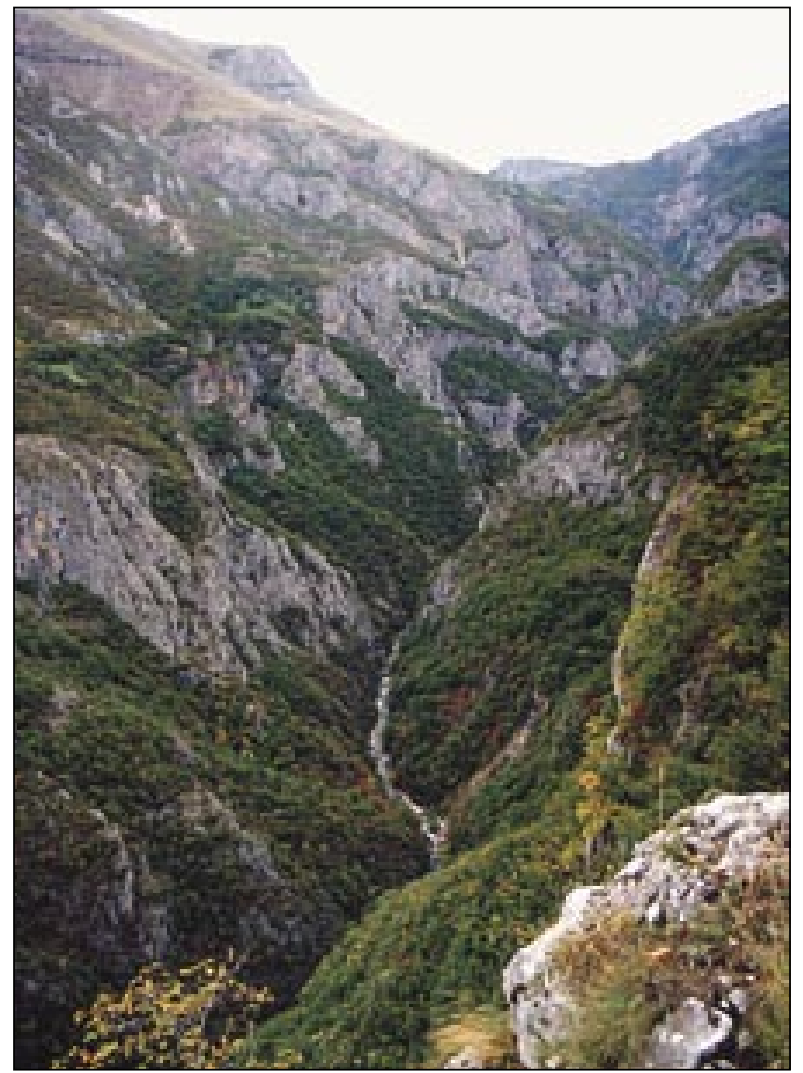

Fig.2: The Rakitnica River valley.
The Rakitnica River is 32 $\mathrm{km}$ long, while the surface of its orographically defined river system is $207 \mathrm{~km}^{2}$. Along 23,5 $\mathrm{km}$ of length, it flows through the canyon-gorge valley at the contact of folded block-thrusted massifs - Mt.Bjelašnica and Mt. Visočica. Upstream from the canyon part of the valley, the surface stream network is developed, with shallow riverbeds and relatively small inclinations of the valley sides. It occupies much wider surface and has greater stream network density compared to the canyon part, thanks to the domination of impermeable Jurassic-Cretaceous flysch. Canyon part of the valley has completely different lithological and morphological characteristics. Triassic limestones, dolomites, and dolomitic limestones, particularly fissured, prevented the development of surface stream network. Apart from the allogenic river Rakitnica, there are only two short permanent streams, several $\mathrm{km}$ 
long - Rijeka and Međeđa. Karst springs in the canyon contribute most significantly to the flow of the Rakitnica. On highly uplifted fluviokarst levelled surfaces on Mts. Bjelašnica and Visočica, into which the Rakitnica is incised, there are karst blind valleys.

The canyon-like part of the Rakitnica valley (Fig.3) occupies the area of $54 \mathrm{~km}^{2}$, or $26,3 \%$ of its entire basin, if it is defined by surface orographic watershed. Three geomorphologic sub-sectors can be distinguished in this relatively small area. The upper sector of the studied part of the valley is a lithological and partially a morphological and structural unit, along $3 \mathrm{~km}$ of the river course. Hypsometrically, it is the highest part of the researched area, composed of Jurassic-Cretaceous clastites. This part of the valley is consequent, directly related to the geologic composition. Its morphostructural border towards the central part of the researched area is defined by the fault zone G.Lukomir - Brvanjske stijene. The central sector occupies the largest area, along $14 \mathrm{~km}$ of the Rakitnica course. This part of the valley is remarkably composite, polymorphic and exceptionally vertically dissected due to neotectonic movements. Downstream from the Dubočani - Grušča fault,

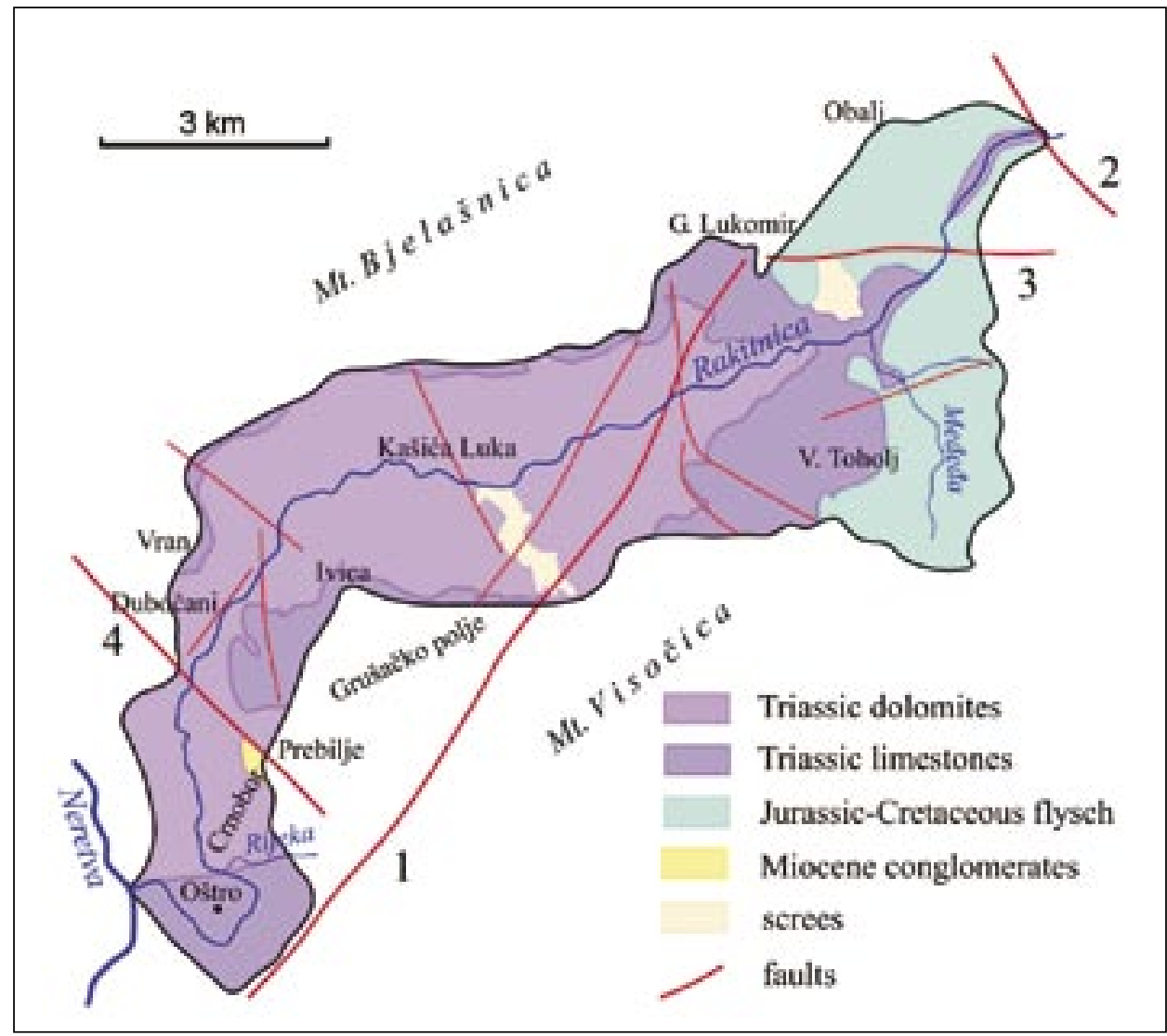

Fig.3: Geological settings and major faults in the researched area (simplified after Mojićević \& Tomić 1981). Faults: 1 - Bahtijevica-Grušča; 2 - Umoljani-Tušila; 3 - fault zone G.Lukomir-Brvanjske stijene; 4 - Dubočani-Džepi. 
there is the lower sector of the valley, the final $7 \mathrm{~km}$ of the Rakitnica course until its mouth to the Neretva River. It has a distinctive sharp bend, and longest portions of extremely narrow vertical-sided parts (even with 1,5 m of width) (Fig.5).

Regarding morphography and morphometry, the valley is remarkably polymorphic, with very dissected relief $\left(500-800 \mathrm{~m} / \mathrm{km}^{2}\right)$ and steep slopes of valley sides.

The longitudinal profile of the riverbed is discordant, with numerous steps which reach the inclinations of $80 \%$. Denivellation from the beginning point of the upper sector riverbed $(1107 \mathrm{~m}$ a.s.l.) to the mouth to the Neretva River (324 m a.s.1.) is $800 \mathrm{~m}$ at the length of $23,5 \mathrm{~km}$. Average riverbed inclination is about $40 \%$.

The valley is widest in hypsometrically highest parts (above $1500 \mathrm{~m}$ a.s.l.), ranging between 2,5 and $3 \mathrm{~km}$. In the downstream direction, the valley width gradually decreases to $2 \mathrm{~km}$ (between Ivica, at $1411 \mathrm{~m}$ a.s.l, and Vran, at $1250 \mathrm{~m}$ a.s.l.), and finally to $750 \mathrm{~m}$ between Oštro (884 $\mathrm{m}$ a.s.l.) and Crnobor (923 m a.s.l.), which is $3 \mathrm{~km}$ before its mouth to the Neretva River. In this part, the riverbed

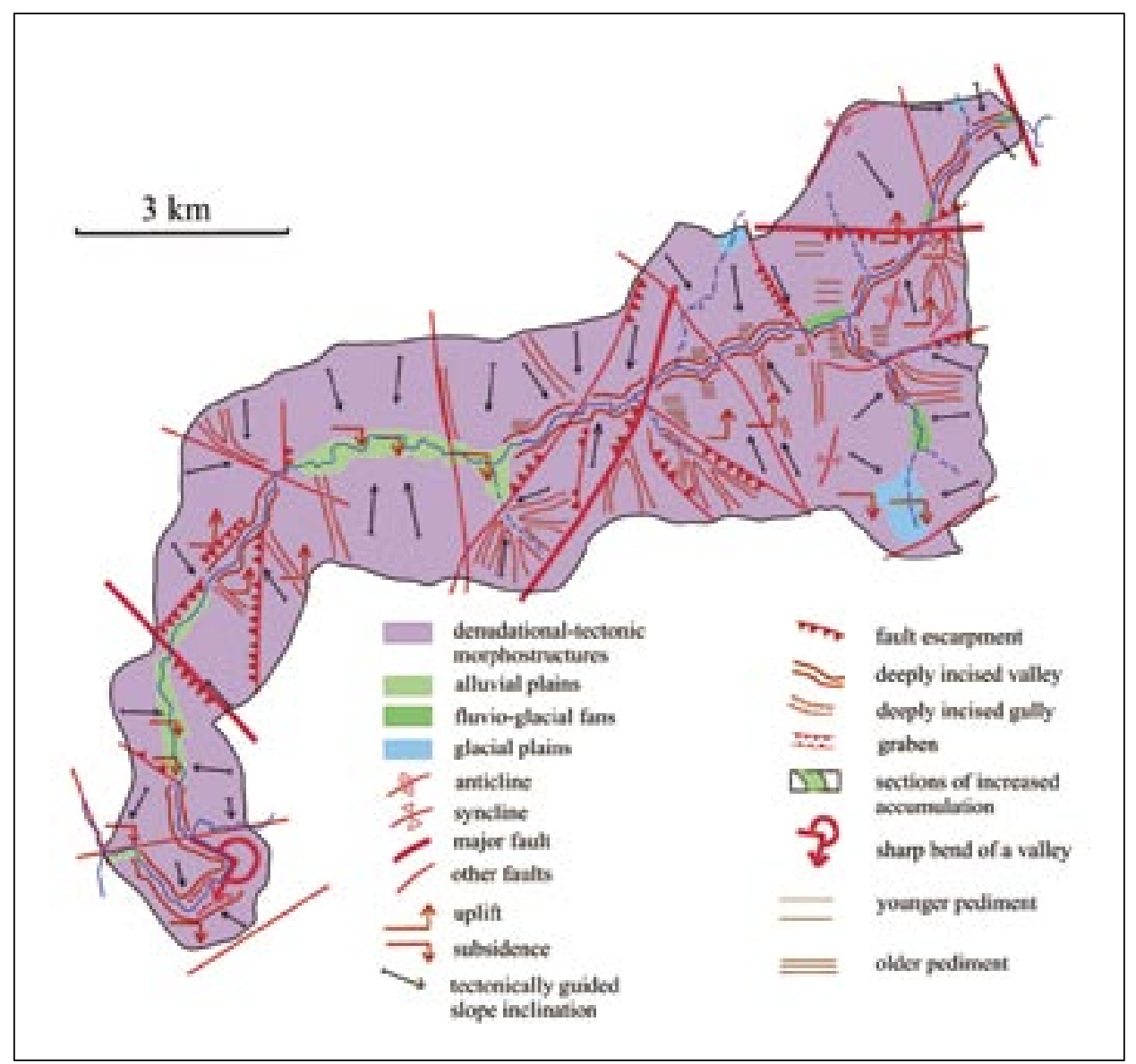

Fig.4: Morphostructural map of the researched area. 
of Rakitnica is narrowest (only 1,5 m), and the course sharply bends due to crossing of two faults. There are seven riverbed sections 2-10 m wide, with occurrences of overhangs. Such morphogenesis is specific, and differs from the usual case (greatest valley width in a junction area).

Cross sections of the valley are usually with 'stepping' slopes and abrupt changes of inclinations. 240-340 m above the riverbed, there are prominent fluviodenudational levels, above which steep slopes continue for the next 700-850 m. Lower parts of valley sides are more symmetrical, especially in narrow parts where the steep scarps exceed the height of $200 \mathrm{~m}$ above the riverbed. The right valley side (the one of Mt.Bjelašnica) is exposed to the south and therefore has poorer vegetation cover, which leads to more intensive denudational and erosional processes. Thus, it is less inclined compared to the left valley side (next to Mt.Visočica).

The relation of the valley direction and the dip of strata indicates that the canyon-gorge part of the Rakitnica valley is consequent and longitudinal only in short part (in the upper section), while

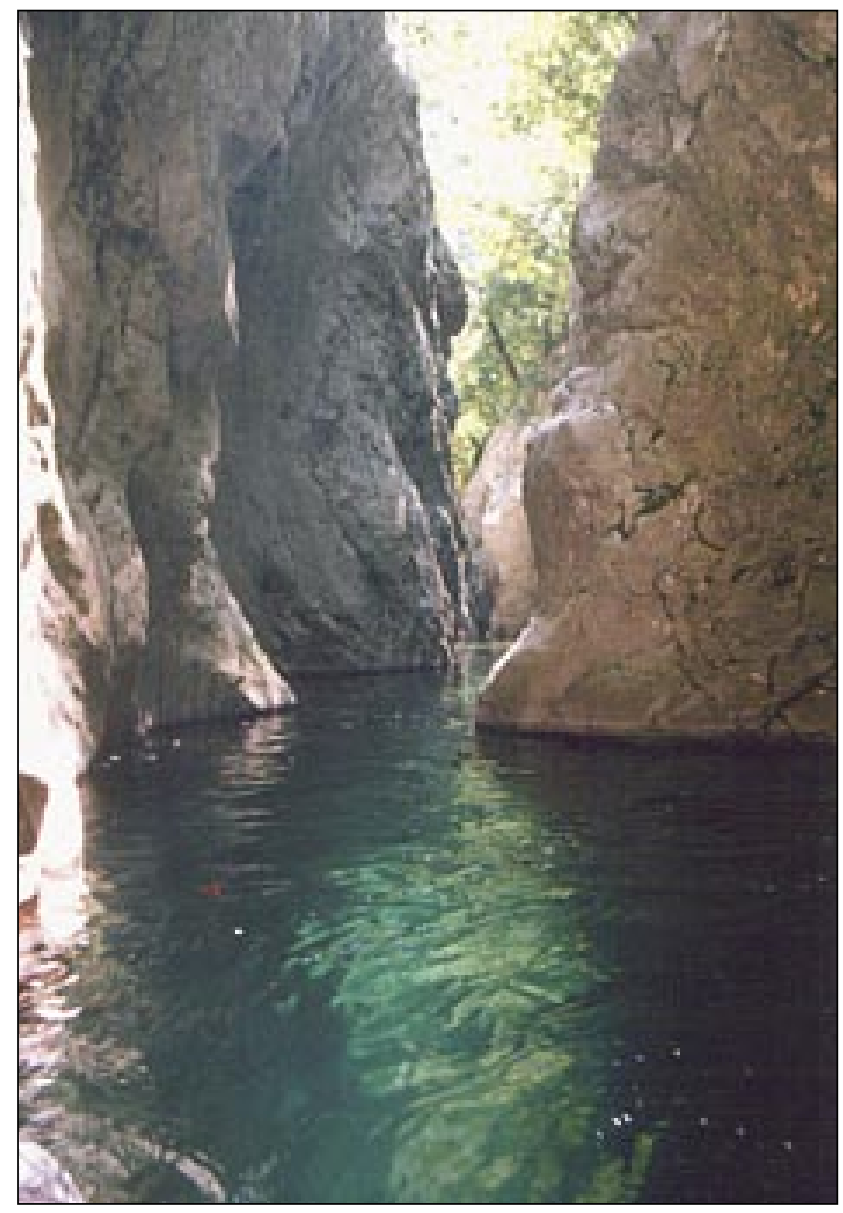

Fig.5: One of the narrowest parts of the Rakitnica canyon, in its downstream part (close to the Oštro peak). in most part it is an obsequent transversal through gorge, cutting the various strata at sharp angles.

Regarding morphogenesis, the valley is polygenetic. During the Neogene-Quaternary uplift of the whole area, fluviokarstic, fluviodenudational, glacial and periglacial processes (erosional and aggradational) took part in formation of the valley. Regarding morphochronology, the valley is polyphase. The Rakitnica is a relatively young stream, which along its whole course has the flow mechanism usually characteristic only to upstream sections. This is primarily the sign of continuous uplift of the area, and lithologically complex composition.

The valley is partially superimposed - in the downstream part, before the sharp bend, it is incised in harder and more resistant Triassic carbonates, while softer Neogene beds are situated close to Dubočani on the right and at the Prebilje pass on the left valley side. 


\section{RELATION BETWEEN RELIEF AND GEOLOGICAL STRUCTURE}

Intensive radial faulting during the Quaternary uplift has guided the formation of deep and relatively narrow canyon-gorge valley of the Rakitnica. These tectonic movements have defined the recent direction of the valley and its characteristic of a through-valley. Particular microtectonic crushing has initiated and directed the strong destructional exogenous geomorphological processes.

Apart from the reverse faults, there are rotational faults as well - rotational movements of microtectonic blocks, especially on left valley sides. While one part of a block is being uplifted, another part, at very small distances, is being subsided. Regarding relief, this reflects in particular hypsometric and morphographic differences between levelled surfaces, and wider parts of valleys as the zones of relative subsidence, and vertical escarpments and steep slopes that represent the zones of relative uplift (Fig.4). Numerous parallel transversal faults within fluviokarstic levelled surfaces of Visočica massif, which overlap their limbs due to small inclinations, have formed a thrust structure and nappes (fluviokarst levelled surface called Grušačko Polje).

Quaternary uplifts have influenced the shaping of recent look of the Rakitnica canyon, especially its deeply incised upper and central sector.

The Rakitnica valley is mostly difficult to pass, especially in narrow parts and close to escarpments. Canyon-gorge part of the valley was mostly photo-geologically analysed during the basic geological mapping at the scale 1:100.000 (Mojićević \& Tomić 1981, 1982; Jovanović et al. 1978). Many lithostratigraphic units in the central sector of the valley and in almost all the narrow parts have been determined only by superposition. In all that area (except ridges and high parts of the massifs Bjelašnica and Visočica) there are no data of stratal dips on the basic geological map. Therefore the relation of the valley to the geological composition was analysed on the basis of extensive fieldwork mapping.

Triassic carbonates in which the Rakitnica valley is developed, have been fractured to several smaller tectonic blocks. Narrow parts are characterized by riverbeds only 1,5 - 6 m wide (Fig.5), and the valley sides are often represented by overhanging escarpments rising even more than 200 $\mathrm{m}$ directly from the riverbed. The mentioned narrowings are situated at the transversal faults or in fault zones. In these hypsometrically lower parts, the valley is unconformable - transversal, because it cuts the strata at sharp angles.

Slopes of the valley sides in lower and central sector of the canyon are formed in vertical, inclined and recumbent folds, which are additionally intensively fractured. In hypsometrically lower parts of the canyon, folded strata are poorly preserved and difficult to notice. It should be mentioned that the right valley side above the widening close to Kašića Luka is represented by slopes of uniform inclinations $\left(30^{\circ}-37^{\circ}\right)$, thanks to uniform lithological composition and the strike of strata at the length of about $3 \mathrm{~km}$. This is the example of a structural slope.

Above $1000 \mathrm{~m}$ a.s.l, to the east of the line G.Lukomir - V. Toholj, the geological composition changes to clastic flysch formations laying transgressively over Triassic carbonates. In the area with flysch deposits, horizontal dissection of relief is increased, and the inclinations of valley sides are smaller. 


\section{CONCLUSION}

Based on the morphometrical and morphostructural analyses, the particular dynamics of relief of the Rakitnica canyon were determined. This has been caused by strong neotectonic uplift movements, with intensive exogenous geomorphologic shaping of relief.

It was determined that the correlation between the valley relief and lithological composition is very high. Regarding the relation between relief and geological structures, the Rakitnica canyon is in its greatest part an unconformable through valley. It is deeply incised and shaped within older folded block-thrusted mountain massifs of Bjelašnica and Visočica, dating from pre-Tertiary and Tertiary folding. The blocks of the mentioned massifs are very active structures, concluding from the amplitudes of recent uplifts. The researched area is typical for clear relief expressions of its structural pattern, which is noticed through types of structurally guided types of valley network, deeply incised valleys, fault escarpments, etc.

The valley is of polygenetic, polymorphic (composite) and polyphase character, with dominant destructional erosion processes. Genetically, it is a relatively young valley whose genesis and development is linked to a neotectonic phase of Dinaric mountain system uplift during the Neogene and the Quaternary.

\section{REFERENCES}

Bognar, A., 1987: Reljef i geomorfološke osobine Jugoslavije.- Veliki geografski atlas Jugoslavije, SNL, Zagreb

Bušatlija, I., 1973: Kanjon Rakitnice.- PD Bjelašnica, Sarajevo

Golubović, Đ., 1976: Dolina Rakitnice.- Diplomski rad, PMF Sarajevo

Jovanović, R., Mojićević, M., Tokić \& S., Rokić, Lj., 1978: Osnovna geološka karta 1:100000, Tumač za list Sarajevo.- Savezni geološki zavod, Beograd

Lepirica, A., 1991: Zabjelašnica - sliv rijeke Rakitnice.- Diplomski rad - Thesis, PMF Sarajevo

Lepirica, A., 2004: Geomorfološke značajke kanjona Rakitnice i njegovo geoekološko vrednovanje.Magistarski rad - Thesis, PMF Zagreb

Mojićević, M. \& Tomić, B., 1981: Osnovna geološka karta 1:100000, List Kalinovik.- Savezni geološki zavod, Beograd

Mojićević, M. \& Tomić, B., 1982: Osnovna geološka karta 1:100000, Tumač za list Kalinovik.Savezni geološki zavod, Beograd 